Animal, Poultry and Fish Production Research

http:/www.journals.zu.edu.eg/journalDisplay.aspx?Journalld=1\&queryType=Master

\title{
DIETARY COMBINATION OF VITAMIN E, SELENIUM, AND ZINC EFFECT ON THE REPRODUCTIVE EFFICIENCY OF NILE TILAPIA (Oreochromis niloticus)
}

\author{
El-Sayed M. Abou El-Fotoh ${ }^{1 *}$, G.A. Abd El-Rahman', M.E. Farag ${ }^{2}$, B.A. Khalil ${ }^{2}$ and M.S. Ayyat ${ }^{2}$ \\ 1. Fish Physiol. Dept., Cent. Lab. Aquac. Res., Abbass, Sharkia, Egypt \\ 2. Anim. Prod. Dept., Fac. Agric., Zagazig Univ., Egypt
}

Received: 01/03/2020 ; Accepted: 17/03/2020

\begin{abstract}
This experiment was conducted to study the effect of combinations between $350 \mathrm{mg}$ vitamin $\mathrm{E}$ with $120 \mathrm{mg}$ zinc $/ \mathrm{kg}$ diet, or $0.3 \mathrm{mg}$ selenium $/ \mathrm{kg}$ diet as feed additives on the reproductive performance of female Nile tilapia (Oreochromis niloticus) diet for 144 days. Growth rate, average weight and number of eggs, egg weight, Relative fecundity, hatching percentage, survival rate of the fry and the concentration of follicle stimulating hormone (FSH) and luteinzing hormone (LH) in the blood serum at the different treatments compared to the control group. The results showed that the increase in the final body weight with vitam. $\mathrm{E}+\mathrm{Zn}$ and vitamE $+\mathrm{Se}$ treatments was $141.80 \pm 0.92$ and $142.00 \pm 1.15 \mathrm{~g}$ and body length was $20.60 \pm 0.06$ and $20.60 \pm 0.06 \mathrm{~cm}$ compared to the control groups $(136.00 \pm 0.92 \mathrm{~g}, 20.30 \pm 0.05 \mathrm{~cm}$, respectively. The results of spawning efficiency showed an increase in average weight of eggs with vitam. $\mathrm{E}+\mathrm{Zn}$ and vitam. $\mathrm{E}+\mathrm{Se}$ treatments valued as much as $2.613 \pm 0.085$ and $2.643 \pm 0.018 \mathrm{~g}$ and the number of eggs produced $453.33 \pm 18.05 \mathrm{and} 475.67 \pm 4.05 \mathrm{egg} / \mathrm{female} /$ spawning compared to the control group $(2.043 \pm 0.074 \mathrm{~g}$ and $365.67 \pm 15.81 \mathrm{egg} / \mathrm{female} / \mathrm{spawning}$, respectively). The relative fecundity of female's recorded the highest value ( $3.20 \pm 0.12$ and $3.35 \pm 0.03$ egg/g of body weight) with vitam. E $+\mathrm{Zn}$ and vitam. E +Se treatments compared to the control group $(2.70 \pm 0.12 \mathrm{egg} / \mathrm{g}$ of body weight $)$. On the other hand, the hatching percentage of eggs in treatment fed on supplementation diet with combination (vitam. E+ Zn) was higher $(87.13 \pm 0.08 \%)$ than the other treatments. Fish fed diets supplemented with vitem. E+ Zn recorded the highest value of FSH, unlike the released hormone, which increased its concentration in blood fish in all treatments. The highest rate of increase in the body weight of fish larvae fed with (vitamin E +Zinc), the highest survival rate was with the fish group fed with a dietary supplement of vitam. E+ selenium).That is to say, female Nile tilapia (O. niloticus) feeding on diet combined with vitamin E, selenium and zinc had the positive effect on growth and reproductive performances in spawning season.
\end{abstract}

Key words: Reproductive, Nile tilapia, dietary, vitamin E, selenium.

\section{INTRODUCTION}

The culture of tilapia is the major interest among many freshwater fishes due to several factors such as high resistance to diseases, excellent growth rate, high yield, tolerance to a wide range of environments and acceptability of natural and artificial feed, several methods have been developed to control reproduction for cost- effective production (El-Sayed, 2006; Olufeagba and Okomoda, 2015; FAO, 2016).

Feed additives, such as micronutrients, and vitamins are commonly administered in feed to improve productive and reproductive performance and to control the outbreak of diseases in aquaculture (Gaunt et al., 2010; Defoirdt et al., 2011). Trace elements are needed for vitamin synthesis, hormone

\footnotetext{
*Corresponding author: Tel. : +201060465491

E-mail address: fotoh22@yahoo.com
} 
production, enzyme activity, energy production and other physiological processes related to growth, reproduction and health (Hayat et al., 2010).

The zinc and selenium results showed their importance for the production of the semen, as it is involved extensively in nucleic acid and protein metabolism (Underwood and Somers, 1969; Surai, 2002).

Zinc is a very important trace element that is involved in a wide range in metabolic activities and productive performances like growth, reproduction and humeral immune system (Prasad and Kundu, 1995; Underwood and Suttle, 1999; Abdel Monem and El-Shahat, 2011). Zinc plays important role in various biological activities in animals (Swinkels et al., 1994). Zinc deficiency causes numerous physical and pathological changes such as growth retardation and decreased immunity to infection of several diseases (Star et al., 2012). Liu et al. (2011) suggested that dietary zinc supplementation improved zinc status and resulted in promoting antioxidant ability and activities and gene expressions of fat metabolism-related enzymes of broilers.

Selenium (Se) is an essential ingredient that plays an important role in animal reproduction. Selenium is an integral component of glutathione peroxidase, an enzyme that protects the inner structures of cells from free radicals and is an antioxidant of cellular membrane lipids (Bartle et al., 1980; Gabryszuk, 1994). Along with a number of functions, selenium plays an important role in the reproductive processes of both male and female livestock (Heimann et al., 1984; Marin-Guzman et al., 2000). Bates et al. (2000) found that Se deficiency has no significant effect on female reproduction. However, Basini and Tamanini (2000) reported that $\mathrm{Se}$ significantly stimulates the proliferation of cells from small follicles, and also enhances oestradiol production.

Vitamin E functions as a lipid-soluble antioxidant that protects biological membranes, lipoproteins and lipid stores against the damage induced by oxygen free radicals and reactive products of lipid peroxidation (Bodas et al., 2011). Antioxidants play an important role in avian reproduction (Bollengier-Lee et al., 1999;
Lin et al., 2004 and 2005). The group of vitamin $\mathrm{E}$ consists of a mixture of vitamins in which the most important is the $\alpha$ - tocopherol that exists in nature accompanied by other compounds, $\beta$-, $\gamma$ - and $\delta$-tocopherols, and whose function is to inhibit or retard oxidation of animal tissue, especially unsaturated fatty acids and vitamin A (Nascimento et al., 2014). The gonadal development and fecundity are affected by certain essential nutrients, especially in species with continuous spawning with short periods of vitellogenesis (Izquierdo et al., 2001). In fish, vitamin $E$ is used for diet supplementation with the purpose of improving growth, resistance to stress and immune system. It is efficient in the conservation of fish during processing and storage, inhibiting the degradation of lipids by oxidation (Webster and Lim, 2001) and also plays an important role in fish reproductive physiology, especially fertility and growth of crustaceans (Conklin, 2000). It is responsible for maintaining the permeability of capillaries and cardiac muscles, and also acts on cellular respiration and in the biosynthesis of DNA (Pezzato et al., 2004). According to Serezli et al. (2010) the effect of vitamin $\mathrm{E}$ on female and male reproductive performance is not to be overemphasized.

The aim of the present work was to verify and compare the effect of a supplementation of selenium, zinc, and vitamin $\mathrm{E}$ on the gonad somatic index, fecundity, egg size, spawning efficiency and hatchability of Nile tilapia (Oreochromis niloticus).

\section{MATERIALS AND METHODS}

The study was conducted at the Department of Animal Production, Agriculture Faculty, Zagazig University and the practical work was carried out at Central Laboratory for Aquaculture Research (CLAR), Abbassa village, Abu-hammad district, Sharkia Governorate, Egypt. The experiment was conducted to study the effect of vitamin $E$ with selenium or zinc as nutritional additives on the reproductive performance of female Nile tilapia and compare them with control for 144 days during the spawning season 2018. 
A total of 108 healthy female Nile tilapia were brought in weight $(70-75 \mathrm{~g})$ and length $(14-15 \mathrm{~cm})$, and the number of 108 healthy male Nile tilapia weight between (90-100 g) and length ranging from $(17-18 \mathrm{~cm})$ at ratio malefemale 1:1 from the hatchery of the Central Laboratory for Fish Research Abbassa to one of the docks research of the laboratory. The fish were divided into three treatments. The first treatment fed diet without any treatment as (control group), the second was supplemented with $350 \mathrm{mg}$ vitamin $\mathrm{E}+120 \mathrm{mg}$ zinc $/ \mathrm{kg}$ diet and the third was supplemented with $350 \mathrm{mg}$ vitamin $\mathrm{E}+0.3 \mathrm{mg}$ selenium $/ \mathrm{kg}$ diet. Water quality was measured every 12 days during the trial period, as the water temperature ranged from $\left(12-31{ }^{\circ} \mathrm{C}\right)$, dissolved oxygen ranged from (5.4 - $7.4 \mathrm{mg} / 1)$ and $\mathrm{pH}(6.9-8)$.

All fish groups were fed on basal pelleted diet consistent of fish meal $30.0 \%$, soybean meal $15.0 \%$, corn $12.0 \%$, wheat bran $19.0 \%$, rice bran $20.0 \%$ molasses $2.75 \%$, minerals mixture $0.75 \%$ and vitamin mixture $0.5 \%$. The chemical composition of the diet was crude protein $32.6 \%$, ether extract $5.9 \%$, and crude fiber $5.7 \%$ and gross energy $4119.0 \mathrm{Kcal} / \mathrm{Kg}$.

The fish of the experiment were distributed on 9 hapas $(4 \times 2 \times 1 \mathrm{~m})$ with water level of 80 $\mathrm{cm}$, held on earthen pond $\left(1000 \mathrm{~m}^{2}\right)$ where from $30-40 \%$ of the water level was changed with fresh water every 4 days. The hapas were divided into four treatments each treatment contained three replicates, each replicate was stoked at density of 24 fish (12 females: 12 males). Fish were fed on experimental diets with $4 \%$ of body weight for the first 23 days of the trial period, and the remaining trial period (24144 days). Fish were fed 3\% of body weight for the end of the experiment and meals were given daily in two batches at 9, 12 in the morning. Fish were weighed at 24-day intervals during the trial period and feed quantities were reset according to changes in live body weight. The body weight was determined by using electrical balance and the survival rate.

Eggs were removed each 12 days from brooder's buccal cavity and number of eggs in each spawn was reported. The total number of eggs per individual fish was estimated by taking total weight of eggs and the mean weight of subsamples containing 100 eggs into account. The mean weight of egg was determined to the nearest $0.001 \mathrm{~g}$ by taking random samples. Eggs are taken from the oral cavity of mothers after each spawn are placed in incubation units (hapa $1 \mathrm{X} 1 \mathrm{X} 1 \mathrm{~m}=1 \mathrm{~m}^{3}$ ). The fertilization rate refers to the ratio of fertilized eggs to the total number of eggs as a percentage. The percentage of egg hatchability is the ratio of number of eggs hatched to the total number of fertilized eggs as a percentage. Larval survival rate is the ratio of number of larvae survived until completely yolk sac absorption to the total number of eggs hatch as percentage. Variables were estimated from the data included the number of spawned eggs and the total egg weight per female were determined. Absolute fecundity equals the number of seeds per spawning female. Relative fecundity equals the number of seeds per weight of female (g). Hatchability performance was checked including the survival yolk-sac fry and swim-up fry after 15 days post-swim up. Hatching rate (\%) was calculated as a percentage of incubated eggs when higher than $90 \%$ of the embryos had hatched. Survival rate percent of larvae after 15 days of hatching = number of live fries / total number.

The data were statistically analyzed with SAS (2004) according to the following model: $Y_{i j}=\mu+T_{i}+e_{i j}$, Where, $\mu$ is the overall mean, $\mathrm{T}_{\mathrm{i}}$ is the fixed effect of treatments and $\mathrm{e}_{\mathrm{ij}}$ is random error. Significant differences between treatments were tested with Duncan's multiple range test (Duncan, 1955).

\section{RESULTS AND DISCUSSION}

\section{Growth Performances of Female Nile Tilapia}

The results of growth performances on female Nile tilapia (O. niloticus) feeding on diet combined with vitamin $\mathrm{E}$, selenium and zinc (vitam $\mathrm{E}+\mathrm{Zn}$ and vitam $\mathrm{E}+\mathrm{Se}$ ) and compared with control diet for 144 days during the spawning season, showed that the increases in the final body weight with vitam $\mathrm{E}+\mathrm{Zn}$ and vitam $\mathrm{E}+\mathrm{Se}$ treatments were $141.80 \pm 0.92$ and $142.00 \pm 1.15 \mathrm{~g}$ also body length increased and valued $20.60 \pm 0.06$ and $20.60 \pm 0.06 \mathrm{~cm}$ compared to the control groups $(136.00 \pm 0.92 \mathrm{~g}$, 
$20.30 \pm 0.05 \mathrm{~cm}$ respectively) as shown in Tables 1 and 2. This increase in growth is a result of the fact that vitamin E and selenium (via glutathione peroxidase) act as parts of a multi-component antioxidant defense system. This system protects cells from the adverse effects of reactive oxidation of polyunsaturated membranous phospholipids. Raederstorff et al. (2015) reported that vitamin $\mathrm{E}$ is one of the major antioxidants in the body and plays a major role in protecting different organs against oxidative stress. Also, the obtained results are agreed with James et al. (2008) who found that feeding golden fish with $300 \mathrm{mg}$ of vitamin $\mathrm{E} / \mathrm{kg}$ diets recorded a significant increase in fish body weight. Le and Fotedar (2013 and 2014) found that weight gain and feed intake were significantly reduced in the yellow squash fish diet that feeds on $3.35 \mathrm{mg}$ of selenium $/ \mathrm{kg}$ diet. As well, Li and Huang (2016) found that Juvenile hybrid tilapia fed on diet containing 31 $\mathrm{mg}$ zinc $/ \mathrm{kg}$ diet showed the lowest growth rates. On the other hand, weight gain increased in fish fed on $127 \mathrm{mg}$ zinc $/ \mathrm{kg}$ diet.

\section{Reproductive Performances of Female Nile Tilapia}

The results of spawning efficiency of female Nile tilapia (O. niloticus) feeding on diet combined vitamin $\mathrm{E}$ with zinc and selenium (vitam $\mathrm{E}+\mathrm{Zn}$ and vitam $\mathrm{E}+\mathrm{Se}$ ) and compared with control diet for 144 days during the spawning season showed an increase in average weight of eggs with vitam. E + Zn and vitam. E + Se treatments, the increment valued $2.613 \pm$ 0.085 and $2.643 \pm 0.018 \mathrm{~g}$ and the number of eggs produced $453.33 \pm 18.05$ and $475.67 \pm 4.05$ egg/female/ spawning compared to the control group $(2.043 \pm 0.074 \mathrm{~g}$ and $365.67 \pm 15.81 \mathrm{egg} /$ female/spawning, respectively), as shown in Tables 3 and 4. While, no significant effect was observed among the experimental groups on egg weight per female as shown in Table 5. That makes clear that there is a positive correlation between the supply of nutrients during vitellogenesis in the broodstock diet and reproductive related factors such as a better oocyte development and maturation, higher rate of vitellogenesis, larger egg size and better embryonic development (Ghosh et al., 2007). In a study of the effects of vitamin $E$ and growth hormone on gonadal maturity in the common carp (Cyprinus carpio), dietary vitamin $\mathrm{E}$ resulted in a higher gonadosomatic index, larger ova, and more eggs with higher hatchability than the control (Gupta et al., 1987).

Selenium represents an integral component of glutathione peroxidase, an enzyme which, protects cell internal structures against free radicals and is an antioxidant for cellular membrane lipids (Bartle et al., 1980 and Gabryszuk, 1994). Besides a number of functions, selenium plays an important role in reproductive processes of both males and females of livestock animals (Heimann et al., 1984 and Marin-Guzman et al., 2000). James et al. (2008) found that females fed the $300 \mathrm{mg}$ vitamin $\mathrm{E} / \mathrm{kg}$ diet had significantly heavier gonads and a higher number of eggs with better hatchability than those fed other diets, Egg weight and diameter and larvae weight and length were significantly higher in fish fed 300 $\mathrm{mg}$ vitamin $\mathrm{E}$ than in fish fed the control diet but did not differ from other vitamin $E$ treatments. Pamungkas et al. (2014) found that supplementation of $\alpha$-tocopherol on the diets of female Nile tilapia with level $225 \mathrm{mg} / \mathrm{kg}$ diet can be useful for improving gonadal development, the number of mature female, percentage of maturation and value of spawning frequency on female tilapia.

The results are of relative fecundity of females (O. niloticus) feeding on diet combined vitamin $\mathrm{E}$ with zinc and selenium (vitam. $\mathrm{E}+\mathrm{Zn}$ and vitam. E+Se) and compared with control diet for 144 days during the spawning season are shown in the Table 6 . Recorded highest value (3.20 0.12 and $3.35 \pm 0.03 \mathrm{egg} / \mathrm{g}$ of body weight) with vitam. $\mathrm{E}+\mathrm{Zn}$ and vitam. $\mathrm{E}+\mathrm{Se}$ treatments compared to the control group (2.70土 $0.12 \mathrm{egg} / \mathrm{g}$ of body weight) respectively. On the other hand, the hatching percentage of eggs in treatment fed on supplementation diet with vitamin $\mathrm{E}+\mathrm{Zn}$ group was higher $(87.13 \pm 0.08 \%)$ followed by the group of vitamin $\mathrm{E}+\mathrm{Se}$ $(86.40 \pm 0.23)$ compared to the control group $(85.02 \pm 0.07)$ as shown in Table 7 . The results of this study are in line with, Nascimento et al. (2014) study on the effect of nutrition for several 
Table 1. Effect of dietary vitamin $E$ with $\mathrm{Zn}$ or Se supplementation during the spawning season on weight (g) of females (O. niloticus)

\begin{tabular}{lccccccc}
\hline Treatment & Initial & 24 day & 48 day & 72 day & 96 day & 120 day & 144 day \\
\hline Control & $72.33 \pm 1.20$ & $88.067^{\mathrm{b}} \pm 0.03$ & $96.50^{\mathrm{b}} \pm 0.35$ & $105.50^{\mathrm{b}} \pm 0.46$ & $115.03^{\mathrm{b}} \pm 0.72$ & $125.03^{\mathrm{b}} \pm 0.84$ & $136.00^{\mathrm{b}} \pm 0.92$ \\
Vitamin E+ Zn & $72.33 \pm 0.66$ & $88.63^{\mathrm{a}} \pm 0.08$ & $97.66^{\mathrm{a}} \pm 0.20$ & $107.60^{\mathrm{a}} \pm 0.40$ & $117.80^{\mathrm{a}} \pm 0.30$ & $129.43^{\mathrm{a}} \pm 0.37$ & $141.80^{\mathrm{a}} \pm 0.92$ \\
Vitamin E+Se & $72.33 \pm 1.20$ & $88.56^{\mathrm{a}} \pm 0.12$ & $97.76^{\mathrm{a}} \pm 0.31$ & $107.80^{\mathrm{a}} \pm 0.11$ & $118.46^{\mathrm{a}} \pm 0.86$ & $129.73^{\mathrm{a}} \pm 1.03$ & $142.00^{\mathrm{a}} \pm 1.15$ \\
Significance & $\mathrm{NS}$ & $* *$ & $*$ & $* *$ & $*$ & $* *$ & $* *$ \\
\hline Where: NS=Not significant & $*=\mathrm{p}<0.05$ & $* * \mathrm{p}<0.01$ & & & & & $*$
\end{tabular}

Where: NS=Not significant $\quad *=\mathrm{p}<0.05 \quad * * \mathrm{p}<0.01$

Table 2. Effect of dietary vitamin $E$ with $\mathrm{Zn}$ or Se supplementation during the spawning season on the length (cm) of females (O. niloticus)

\begin{tabular}{lccccccc}
\hline Treatment & Initial & 24day & 48day & 72day & 96day & 120day & 144day \\
\hline Control & $14.46 \pm 0.26$ & $16.53 \pm 0.03$ & $17.33 \pm 0.16$ & $18.50^{\mathrm{b}} \pm 0.05$ & $19.16^{\mathrm{b}} \pm 0.03$ & $19.70^{\mathrm{b}} \pm 0.05$ & $20.30^{\mathrm{b}} \pm 0.05$ \\
Vitamin E+ Zn & $14.43 \pm 0.12$ & $16.40 \pm 0.20$ & $17.70 \pm 0.05$ & $18.70^{\mathrm{a}} \pm 0.05$ & $19.33^{\mathrm{a}} \pm 0.03$ & $19.96^{\mathrm{a}} \pm 0.03$ & $20.60^{\mathrm{a}} \pm 0.06$ \\
Vitamin E+Se & $14.46 \pm 0.20$ & $16.76 \pm 0.09$ & $17.66 \pm 0.03$ & $18.73^{\mathrm{a}} \pm 0.03$ & $19.40^{\mathrm{a}} \pm 0.06$ & $20.00^{\mathrm{a}} \pm 0.05$ & $20.60^{\mathrm{a}} \pm 0.06$ \\
Significance & NS & NS & NS & $*$ & $*$ & $*$ & $*$ \\
\hline
\end{tabular}

Where: NS=Not significant $\quad *=\mathrm{p}<0.05$

Table 3. Effect of dietary vitamin $E$ with $\mathrm{Zn}$ or Se supplementation during the spawning season on Eggs weight (g) per female (O. niloticus)

\begin{tabular}{lcccccc}
\hline Treatment & $\mathbf{2 4}$ day & $\mathbf{4 8}$ day & $\mathbf{7 2}$ day & 96 day & 120 day & 144 day \\
\hline Control & $0.818 \pm 0.029$ & $1.032 \pm 0.027$ & $1.247 \pm 0.014$ & $1.450 \pm 0.045$ & $1.873 \pm 0.037$ & $2.043 \pm 0.074$ \\
Vitamin E+ Zn & $0.787 \pm 0.008$ & $1.037 \pm 0.035$ & $1.363 \pm 0.022$ & $1.597 \pm 0.035$ & $2.167 \pm 0.060$ & $2.613 \pm 0.085$ \\
Vitamin E+Se & $0.774 \pm 0.020$ & $0.975 \pm 0.020$ & $1.283 \pm 0.042$ & $1.533 \pm 0.068$ & $2.127 \pm 0.067$ & $2.643 \pm 0.018$ \\
Significance & $\mathrm{NS}$ & $\mathrm{NS}$ & $\mathrm{NS}$ & $\mathrm{NS}$ & $\mathrm{NS}$ & $\mathrm{NS}$ \\
\hline Where: NS=Not significant & & & & & &
\end{tabular}

Table 4. Effect of dietary vitamin $E$ with $\mathrm{Zn}$ or Se supplementation during the spawning season on Eggs No per femal per hapa per spawn of (O. niloticus)

\begin{tabular}{lcccccc}
\hline Treatment & 24 day & 48 day & 72 day & 96 day & 120 day & 144 day \\
\hline Control & $176.00 \pm 7.50$ & $211.66 \pm 6.69$ & $242.33 \pm 3.84$ & $276.00 \pm 10.78$ & $346.67 \pm 9.21$ & $365.67^{\mathrm{b}} \pm 15.81$ \\
Vitamin E+ Zn & $168.67 \pm 2.60$ & $210.00 \pm 6.08$ & $263.33 \pm 6.69$ & $298.00 \pm 9.29$ & $389.67 \pm 13.74$ & $453.33^{\mathrm{a}} \pm 18.05$ \\
Vitamin E+Se & $168.33 \pm 5.21$ & $205.00 \pm 3.78$ & $258.33 \pm 6.36$ & $296.33 \pm 11.41$ & $397.33 \pm 15.26$ & $475.67^{\mathrm{a}} \pm 4.05$ \\
Significance & NS & $\mathrm{NS}$ & $\mathrm{NS}$ & $\mathrm{NS}$ & $\mathrm{NS}$ & $* *$ \\
\hline Where: NS=Not significant & \multicolumn{2}{c}{$* * \mathrm{p}<0.01$} & & &
\end{tabular}


Table 5. Effect of dietary vitamin $E$ with $\mathrm{Zn}$ or Se supplementation during the spawning season on weight of one $\mathrm{Egg}(\mathrm{mg}) /$ female (O. niloticus)

\begin{tabular}{lcccccc}
\hline Treatment & 24 day & 48 day & 72 day & 96 day & 120 day & 144 day \\
\hline Control & $4.65 \pm 0.029$ & $4.88 \pm 0.051$ & $5.14 \pm 0.023$ & $5.26 \pm 0.069$ & $5.41 \pm 0.063$ & $5.59 \pm 0.042$ \\
vitamE + Zn & $4.67 \pm 0.033$ & $4.93 \pm 0.032$ & $5.18 \pm 0.056$ & $5.36 \pm 0.049$ & $5.56 \pm 0.047$ & $5.77 \pm 0.045$ \\
vitamE + Se & $4.60 \pm 0.057$ & $4.72 \pm 0.088$ & $4.97 \pm 0.086$ & $5.17 \pm 0.052$ & $5.35 \pm 0.072$ & $5.56 \pm 0.084$ \\
Significance & NS & NS & NS & NS & NS & NS \\
\hline
\end{tabular}

Where: NS=Not significant

Table 6. Effect of dietary vitamin $E$ with $Z n$ or Se supplementation during the spawning season on relative fecundity of $(O$. niloticus)

\begin{tabular}{lcccccc}
\hline Treatment & 24 day & 48 day & 72 day & 96 day & 120 day & 144 day \\
\hline Control & $2.00 \pm 0.09$ & $2.21 \pm 0.0$ & $2.30 \pm 0.03$ & $2.40 \pm 0.09$ & $2.55 \pm 0.06$ & $2.70^{\mathrm{b}} \pm 0.12$ \\
Vitamin E+ Zn & $1.90 \pm 0.03$ & $2.15 \pm 0.06$ & $2.45 \pm 0.06$ & $2.52 \pm 0.07$ & $2.75 \pm 0.09$ & $3.20^{\mathrm{a}} \pm 0.12$ \\
Vitamin E+Se & $1.90 \pm 0.06$ & $2.07 \pm 0.02$ & $2.40 \pm 0.06$ & $2.50 \pm 0.09$ & $2.80 \pm 0.12$ & $3.35^{\mathrm{a}} \pm 0.03$ \\
Significance & $\mathrm{NS}$ & $\mathrm{NS}$ & $\mathrm{NS}$ & $\mathrm{NS}$ & $\mathrm{NS}$ & $* *$ \\
\hline Where: NS=Not significant & $* * \mathrm{p}<0.01$ & & & & &
\end{tabular}

Table 7. Effect of dietary vitamin $\mathrm{E}$ with $\mathrm{Zn}$ or Se supplementation during the spawning season on hatching percentage of (O. niloticus)

\begin{tabular}{lcccccc}
\hline Treatment & $\mathbf{2 4}$ day & $\mathbf{4 8}$ day & $\mathbf{7 2}$ day & $\mathbf{9 6}$ day & 120 day & 144 day \\
\hline Control & $79.02^{\mathrm{b}} \pm 0.09$ & $84.00^{\mathrm{c}} \pm 0.23$ & $88.15^{\mathrm{b}} \pm 0.21$ & $88.05^{\mathrm{b}} \pm 0.29$ & $85.05^{\mathrm{b}} \pm 0.15$ & $85.02^{\mathrm{c}} \pm 0.07$ \\
Vitamin E+ Zn & $78.99^{\mathrm{b}} \pm 0.00$ & $86.03^{\mathrm{a}} \pm 0.03$ & $88.05^{\mathrm{b}} \pm 0.24$ & $88.38^{\mathrm{b}} \pm 0.08$ & $86.25^{\mathrm{a}} \pm 0.06$ & $87.13^{\mathrm{a}} \pm 0.08$ \\
Vitamin E+Se & $80.00^{\mathrm{a}} \pm 0.01$ & $85.03^{\mathrm{b}} \pm 0.03$ & $90.15^{\mathrm{a}} \pm 0.20$ & $89.33^{\mathrm{a}} \pm 0.12$ & $86.10^{\mathrm{a}} \pm 0.15$ & $86.40^{\mathrm{b}} \pm 0.23$ \\
Significance & $* * *$ & $* * *$ & $* * *$ & $* *$ & $* * *$ & $* * *$ \\
\hline Where: $\quad{ }^{* *} \mathrm{p}<0.01$ & $* * * \mathrm{p}<0.001$ & & & & &
\end{tabular}

different levels of vitamin $\mathrm{E}(200,300,400$, and $500 \mathrm{mg} \mathrm{kg}^{-1}$ ) on the reproductive of female Nile tilapia for a period of 90 days. Note an increase in the rate of hatching by $62 \%$ with a level of $400 \mathrm{mg} / \mathrm{kg}$ compared to the lowest supplement level (200 mg).

Sex steroids hormones as affected by feeding on vitamin $\mathrm{E}$ with $\mathrm{Zn}$ or Se supplementation during the spawning season on follicular stimulating (FSH) and luteinizing hormones (LH) of female. In Table 8, the results of FSH hormone in serum of Nile tilapia females fed diet supplemented with studded feed additives increased significantly, while the concentration of LH insignificantly affected. Female Nile tilapia fed diet supplemented with vitamin $\mathrm{E}$ and zinc recorded higher concentration of FSH then these females group. Sex steroids are implicated in many important physiological processes in all vertebrates, and measurement of blood sexual hormones seems to be a valuable tool for assessing the reproductive cycle of fish (Guerrero et al., 2009). 
Table 8. Effect of dietary vitamin $E$ with $\mathrm{Zn}$ or Se supplementation during the spawning season on follicular stimulating (FSH) and lectuinazing hormones (LH) of $O$. niloticus females

\begin{tabular}{lcc}
\hline Treatment & FSH & LH \\
\hline Control & $0.056^{\mathrm{c}} \pm 0.003$ & $0.166 \pm 0.033$ \\
Vitam. E + Zn & $0.100^{\mathrm{a}} \pm 0.006$ & $0.133 \pm 0.033$ \\
vitamE +Se & $0.073^{\mathrm{b}} \pm 0.003$ & $0.166 \pm 0.033$ \\
Significance & $* * *$ & NS \\
\hline
\end{tabular}

Where: NS=Not significant $\quad * * * \mathrm{p}<0.001$

\section{Conclusion}

That is to say, female Nile tilapia $(O$. niloticus) feeding on diet combined with vitamin E, selenium and zinc had the positive effect on growth and reproductive performances in spawning season.

\section{REFERENCES}

Abdel Monem, U.M. and K.H. El-Shahat (2011). Effect of different dietary levels of inorganic zinc oxide on Ovarian activities, Reproductive performance of Egyptian Baladi ewes and growth of their lambs. Bulgarian J. Vet. Med., 14 (2): 116-123.

Bartle, J.L., P.L. Senger and J.K. Hillers (1980). Influence of injected selenium in dairy bulls on blood and semen selenium, glutathione peroxidase and seminal quality. Biol. Reprod., 23: 1007-1013.

Basini, G. and C. Tamanini (2000). Selenium stimulates estradiol production in bovine granulosa cells: possible involvement of nitric oxide. Domestic Anim. Endocrinol., 18: 1-17.

Bates, J.M., V.L. Spate, J.S .Morris, D.L. St Germain and V.A. Galton (2000). Effects of selenium deficiency on tissue selenium content, deiodinase activity, and thyroid hormone economy in the rat during development. Endocrinol., 141: 2490-2500.

Bodas, R., N. Prieto, O. López-Campos, F.J. Giráldez and S. Andrés (2011). Naringin and vitamin $\mathrm{E}$ influence the oxidative stability and lipid profile of plasma in lambs fed fish oil. Res. Vet. Sci., 91 (1): 98-102.
Bollengier-Lee, S., P.E. Williams, C.C. Whitehead (1999). Optimal dietary concentration of vitamin $\mathrm{E}$ for alleviating the effect of heat stress on egg production in laying hens. British Poult. Sci., 40: 102-107.

Conklin, D.E. (2000). Diet. Housing, Maintenance and Breeding. Washington, D.C.; Academic Press.

Defoirdt, T., P. Sorgeloos and P. Bossier (2011). Alternatives to antibiotics for the control of bacterial disease in aquaculture. Current Opinion in Microbiol., 14:251-258.

Duncan, D.B. (1955) Multiple Range and Multiple F-Test. Biometrics, 11: 1-5.

El-Sayed, M.A. (2006). Tilapia Culture. Edited by CABI Publishing, Cambridge, USA, 277.

FAO (2016). The State of World Fisheries and Aquaculture 2016. Contributing to food security and nutrition for all. Rome. 200: 23.

Gabryszuk, M. (1994). The effect of selected minerals and vitamin $\mathrm{E}$ on the reproduction. Anim. Sci. Pap. Rep., 12 (1): 53-61.

Gaunt, P.S., R. Endris, A. McGinnis, W. Baumgartner, A. Camus, J. Steadman, D. Sweeney and F. Sun (2010). Determination of florfenicol dose rate in feed for control of mortality in Nile tilapia infected with Streptococcus iniae. J. Aquatic Anim. Heal., 22: 158-166.

Ghosh, S., A. Sinha and C. Sahu (2007). Effect of probiotic on reproductive performance in female livebearing ornamental fish. Aquac. Res., 38: 518-526. 
Guerrero L., M.D. Guardia, J. Xicola, W. Verbeke, F. Vanhonacker, S. ZakowskaBiemans, M.Sajdakowska, C. SulmontRosse, S. Issanchou, M. Contel, M.L. Scalvedi, B.S. Granli and M. Hersleth (2009). Consumer-driven defi nition of traditional food products and innovation in traditional foods. A qualitative cross-cultural study. Appetite, 52: 345-354.

Gupta, M.L., S.R. Sharma, A. Sundar and S.B. Singh (1987). Geothermal studies in the Hyderabad granitic region and the crustal thermal structure of the Southern Indian Shield. Tectonophysics, 140 (2-4): 257-264.

Hayat, H.M., M.A. Howeda and A.S. El-Wakeel (2010). Effect of zinc methionine supplementation on reproductive performance, kid's performance, minerals profile and milk quality in early lactating Baladi goats. World Appl. Sci. J., 9: 275282.

Heimann E.D., M.F. Smith, J.S. Morris, T.J. Gall, R.G. Elmore and R.E. Morrow (1984). Relationships among spermatozoal anormalities and the selenium concentration of blood plasma, semen, and reproductive tissues in young bulls. Anim. Reprod. Sci. 7: 315-321.

Izquierdo M.S., H. Fernandez-Palacios and A.G.J. Tacon (2001). Effect of brood stock nutrition on reproductive performance offish. Aquac., 197: 25-42.

James, T.C., J. Usher, S. Campbells and U. Bond (2008). Lager yeasts possess dynamic genomes that undergo rearrangements and gene amplification in response to stress. Curr. Genet., 53 (3):139-52

Le, K.T. and R. Fotedar (2013). Dietary selenium requirement of yellowtail kingfish (Seriola lalandi). Agric. Sci., 4(6A): 68-75.

Le, K.T. and R. Fotedar (2014). Toxic effects of excessive levels of dietary selenium in juvenile yellowtail kingfish (Seriola lalandi). Aquac., 433: 229-234.

Li, M.R. and C.H. Huang, (2016). Effect of dietary zinc level on growth, enzyme activity and body trace elements of hybrid tilapia,
Oreochromis niloticus X O. aureus, fed soya bean meal-based diets. Aquac. Nutr., 22: 1320-1327.

Lin Y.F., S.J. Chang and A.L. Hsu (2004). Effects of supplemental vitamin E during the laying period on the reproductive performance of Taiwan native chickens. British Poult. Sci., 45 (6): 807-814.

Lin Y.F., S.J. Chang, J.R. Yang, Y.P. Lee and A.L. Hsu (2005). Effects of supplemental vitamin $\mathrm{E}$ during the mature period on the reproduction performance of Taiwan Native Chicken cockerels. British Poult. Sci., 46 (3): 366-373.

Liu, Z., Y. Huang, Y. Zhang, D. Chen, Y.Q. Zhang (2011). Drosophila Acyl-CoA Synthetase Long-Chain Family Member 4 Regulates Axonal Transport of Synaptic Vesicles and Is Required for Synaptic Development and Transmission. J. Neurosci., 31 (6): 2052-2063.

Marin-Guzman, J., D.C. Mahan and R. Whitmoyer (2000). Effect of dietary selenium and vitamin $\mathrm{E}$ on the ultrastructure and ATP concentration of boar spermatozoa, and the efficiacy of added sodium selenite in extended semen on sperm motility. J. Anim. Sci., 78: 1544-1550.

Nascimento, T.H.R., M.V. de Stéfani, E.B. Malheiros and T.C.D. Koberstein (2014). High levels of dietary vitamin $\mathrm{E}$ improve the reproductive performance of female Oreochromis niloticus. Acta Scientiarum. Biol. Sci., 36 (1): 19-26.

Olufeagba, S.O. and V.T. Okomoda (2015). Preliminary report on the use of Androgen for the production of All-male Oreochromis niloticus. Int. J. Aquac., 5 (9): 1-3.

Palma-Guerrero, J., I.C. Huang, H.B. Jansson, J. Salinas, L.V. Lopez-Llorca and N.D. Read (2009). Chitosan permeabilizes the plasma membrane and kills cells of Neurospora crassa in an energy dependent manner. Fungal Genet. and Biol., 46 (8): 585-594. doi:10.1016/j.fgb.2009.02.010

Pamungkas, F.A., A. Batubara and D. Anwar (2014). Kriopreservasi spermatozoa kambing Boer: perbandingan dua bahan pengencer 
terhadap kualitas post-thawing dan kemampuan fertilisasinya. Jurnal Ilmu Ternak dan Veteriner 19: 130-13.

Pezzato, L.E., M.M. Barros, D.M. Fracalossi, J.E.P. Cyrino and D.P. Nutrição (2004). In: Cyrino, J.E.P.; Urbinati, E.C.; Fracalossi, D. M.; Castagnolli, N. (Ed.). Tópicos especiais em piscicultura de água doce tropical intensiva. São Paulo: Tec Art, 75-169.

Prasad, T. and M.S. Kundu (1995). Serum IgG and IgM responses to sheep red blood cells (SRBC) in weaned calves fed milk supplemented with $\mathrm{Zn}$ and $\mathrm{Cu}$. Nutr., 11: 712-715.

Raederstorff, D., A. Wyss, P.C. Calder, P. Weber and M. Eggersdorfer (2015). Vitamin $\mathrm{E}$ function and requirements in relation to PUFA. British J. Nutr., 114: 1113-1122.

SAS (2004). Statistical Analysis System, User's Guide. Statistical. Version $7^{\text {th }}$ Ed. SAS. Inst. Inc. Cary. N.C. USA

Serezli, R., S. Akhan and S.F. Delihasan (2010). The Effect of Vitamin E on Black Sea Trout (Salmo labrax) Broodstock Performance. Kafkas Universitesi Veteriner Fakultesi Dergisi, 16 (Suppl-B): 219-222.
Star, L., J.D.van der Klis, C. Rapp and T.L. Ward (2012). Bioavailability of organic and inorganic zinc sources in male broilers. Poult. Sci., 91: 3115-3120.

Surai, P.F. (2002). Natural Antioxidants in Avian Nutrition and Reproduction. Nottingham Univ.Press, Nottingham.

Swinkels J.W., E.T. Kornegay and M.W. Verstegen (1994). Biology of zinc and biological value of dietary organic zinc complexes and chelates. Nutr. Res. Rev., 7: 129-149

Underwood, E.J. and M. Somers (1969). Studies of zinc nutrition in sheep 1. The relation of zinc to growth, testicular development and spermatogenesis in young rams. Aust. J. Agric. Res., 20: 889-897.

Underwood, E.J. and N.F. Suttle (1999). In: The mineral nutrition of livestock, $3^{\text {rd }}$ Ed. CABI Publishing, CAB International, Wallingford, Oxon, UK. Technol., 93: 193- 203.

Webster, C.D. and C.E. Lim (2001). Nutrient Requirements and Feeding of Finfish for Aquaculture. Aquac. Int., 9:367-368. 


\section{تأثير التغذية على مخلوط من فيتامين هـ والسيلينيوم والزنك على الكفاءة التناسلية} لأسمالك البلطى النيلى (Oreochromis niloticus)

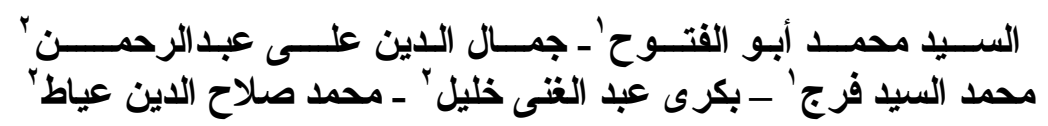

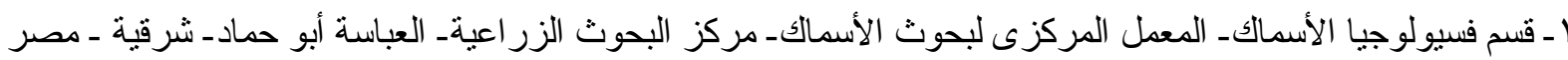

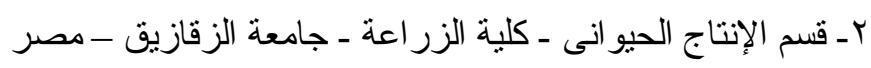

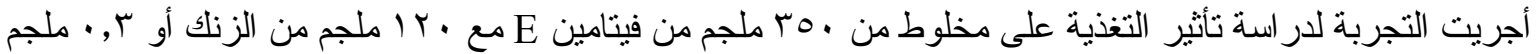

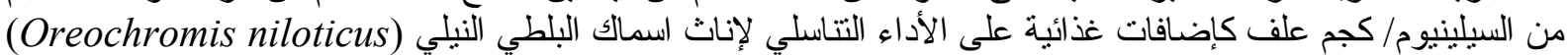

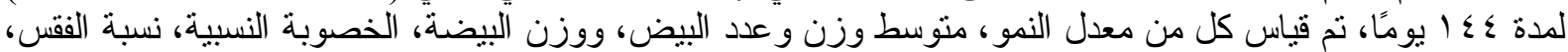

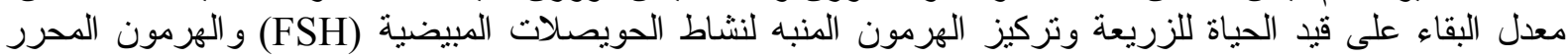

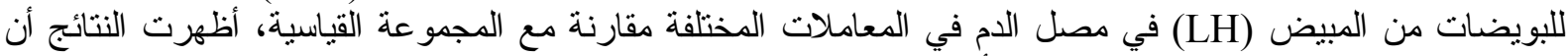

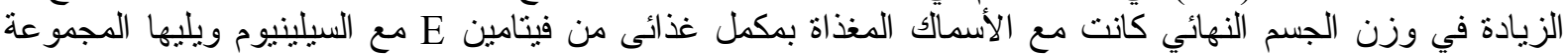

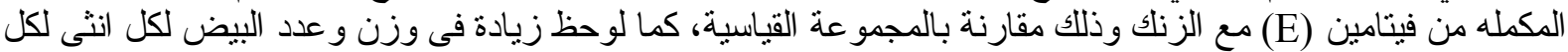

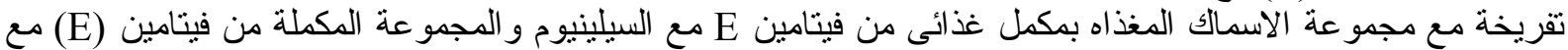

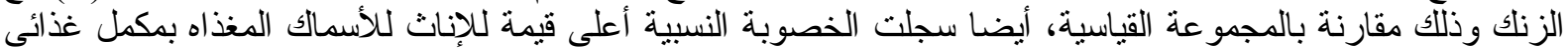

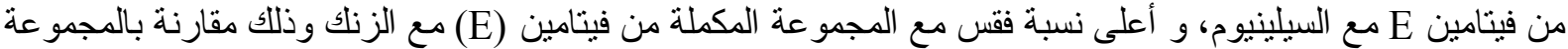

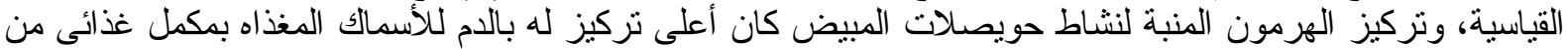

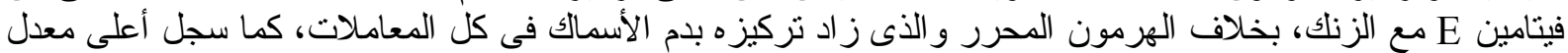

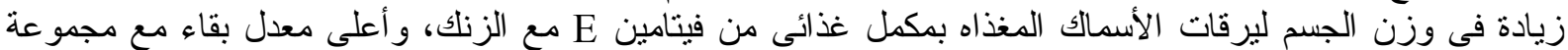

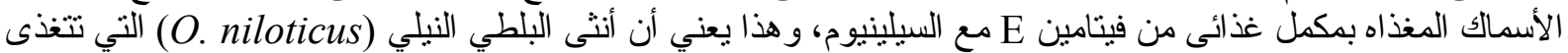

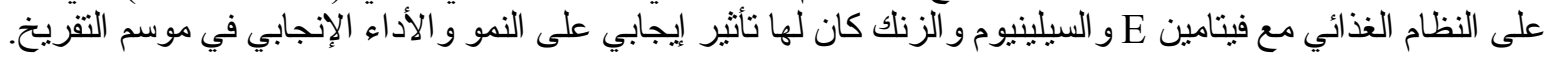

